\title{
Genome analyses of the carboxydotrophic sulfate-reducers Desulfotomaculum nigrificans and Desulfotomaculum carboxydivorans and reclassification of Desulfotomaculum caboxydivorans as a later synonym of Desulfotomaculum nigrificans
}

Michael Visser ${ }^{1}$, Sofiya N. Parshina ${ }^{2}$, Joana I. Alves ${ }^{3}$, Diana Z. Sousa ${ }^{1,3}$, Inês A. C. Pereira ${ }^{4}$, Gerard Muyzer ${ }^{5}$, Jan Kuever ${ }^{6}$, Alexander V. Lebedinsky², Jasper J. Koehorst ${ }^{7}$, Petra Worm', Caroline M. Plugge ${ }^{1}$, Peter J. Schaap ${ }^{7}$, Lynne A. Goodwin ${ }^{8,9}$, Alla Lapidus ${ }^{10,11}$, Nikos C. Kyrpides $^{8}$, Janine C. Detter ${ }^{9}$, Tanja Woyke ${ }^{8}$, Patrick Chain ${ }^{8,9}$, Karen W. Davenport ${ }^{8,9}$, Stefan Spring $^{12}$, Manfred Rohde ${ }^{13}$, Hans Peter Klenk ${ }^{12}$, Alfons J.M. Stams ${ }^{1,3}$

${ }^{1}$ Laboratory of Microbiology, Wageningen University, Wageningen, The Netherlands ${ }^{2}$ Wingradsky Institute of Microbiology, Russian Academy of Sciences, Moscow, Russia ${ }^{3}$ Centre of Biological Engineering, University of Minho, Braga, Portugal

${ }^{4}$ Instituto de Tecnologia Quimica e Biologica, Universidade Nova de Lisboa, Oeiras, Portugal

${ }^{5}$ Department of Aquatic Microbiology, Institute for Biodiversity and Ecosystem Dynamics, University of Amsterdam, Amsterdam, The Netherlands

${ }^{6}$ Department of Microbiology, Bremen Institute for Materials Testing, Bremen, Germany

${ }^{7}$ Laboratory of Systems and Synthetic Biology, Wageningen University, Wageningen, The Netherlands

${ }^{8}$ DOE Joint Genome Institute, Walnut Creek, California, USA

${ }^{9}$ Los Alamos National Laboratory, Bioscience Division, Los Alamos, New Mexico, USA

${ }^{10}$ Theodosius Dobzhansky Center for Genome Bionformatics, St. Petersburg State University, St. Petersburg, Russia

11 Algorithmic Biology Lab, St. Petersburg Academic University, St. Petersburg, Russia

${ }^{12}$ Leibniz Institute DSMZ - German Collection of Microorganisms and Cell Cultures, Braunschweig, Germany

${ }^{13} \mathrm{HZI}$ - Helmholtz Centre for Infection Research, Braunschweig, Germany

Correspondence: Michael Visser (michaelwendy8@gmail.com)

Keywords: Thermophilic spore-forming anaerobes, sulfate reduction, carboxydotrophic, Peptococcaceae, Clostridiales.

Desulfotomaculum nigrificans and D. carboxydivorans are moderately thermophilic members of the polyphyletic spore-forming genus Desulfotomaculum in the family Peptococcaceae. They are phylogenetically very closely related and belong to 'subgroup a' of the Desulfotomaculum cluster 1. D. nigrificans and $D$. carboxydivorans have a similar g rowth substrate spectrum; they can grow with glucose and fructose as electron donors in the presence of sulfate. Additionally, both species are able to ferment fructose, although fementation of glucose is only reported for $D$. carboxydivorans. D. nigrificans is able to grow with $20 \%$ carbon monoxide (CO) coupled to sulfate reduction, while $D$. carboxydivorans can grow at $100 \% \mathrm{CO}$ with and without sulfate. Hydrogen is produced during growth with $\mathrm{CO}$ by $\mathrm{D}$. carboxydivorans. Here we present a summary of the features of $D$. nigrificans and $D$. carboxydivorans together with the description of the complete genome sequencing and annotation of both strains. Moreover, we compared the genomes of both strains to reveal their differences. This comparison led us to propose a reclassification of $D$. carboxydivorans as a later heterotypic synonym of $D$. nigrif icans. 


\section{Introduction}

In 1965, the genus Desulfotomaculum was created for sulfate-reducing bacteria that form heatresistant spores [1]. One of the first species that was included in this new genus was $D$. nigrificans Delft 74, which was originally described as "Clostridium nigrificans" by Werkman and Weaver (1927) [2]. Later, Starkey (1938) renamed it to "Sporovibrio desulfuricans" [3] before it was finally renamed as $D$. nigrificans [1]. $D$. nigrificans is a moderate thermophile that typically grows with fructose and glucose coupled to sulfate reduction $[1,4]$; without sulfate, only growth with fructose was observed. Utilizing sugars is rare among Desulfotomaculum species. Additionally, $D$. nigrificans was described to be able to grow with a number of other substrates including lactate, ethanol, alanine, formate, and carbon monoxide $(20 \%)$ coupled to sulfate reduction $[5,6]$.

Another moderately thermophilic Desulfotomaculum species that can grow with glucose and CO is D. carboxydivorans CO-1-SRB [6]. D. carboxydivorans was isolated from sludge in an anaerobic bioreactor treating paper mill wastewater [6] and was described to be the first sulfate-reducing bacterium able to grow at $100 \%$ CO. D. carboxydivorans converted CO in the presence and absence of sulfate and produced hydrogen during CO conversion. D. carboxydivorans can also grow with glucose. In contrast to $D$. nigrificans, $D$. carboxydivorans degrades glucose both with and without sulfate.

Phylogenetically, D. carboxydivorans is most closely related to $D$. nigrificans. However, D. nigrificans is not able to produce hydrogen from CO. Therefore, by comparing the genomes of these strains, the physiological differences might be explained. Here we present a summary of the features of $D$. nigrificans and D. carboxydivorans, together with the description of the complete genome sequencing and annotation of both strains. Moreover, we compared the genomes of both strains to reveal differences between these phylogenetically very closely related strains. This comparison led us to propose to that $D$. carboxydivorans is a later heterotypic synonym of $D$. nigrificans.

\section{Classification and features}

Comparison of the 16S rRNA gene sequences of $D$. carboxydivorans CO-1-SRB DSM 14880 and D. nigrificans DSM 574 revealed that the two bacteria are highly related (99\% sequence similarity). Both strains are part of the Desulfotomaculum cluster 1 subgroup a, together with $D$. aeronauticum, $D$. putei, D. hydrothermale, "D. reducens" and $D$. ruminis (Figure 1 ).

D. nigrificans and D. carboxydivorans are Grampositive, sulfate-reducing, rod shaped bacteria with rounded ends $0.3-0.5 \mu \mathrm{m}$ thick and 3-6 $\mu \mathrm{m}$ long [1]; 0.5-1.5 $\mu \mathrm{m}$ thick and 5-15 $\mu \mathrm{m}$ long [6], respectively) (Figure 2 and Figure 3). They have a similar temperature range for growth and can both grow optimally at $55^{\circ} \mathrm{C}$. Additional similarities can be found in the substrates used for growth. Both D. nigrificans and D. carboxydivorans can grow with fructose, glucose and alanine. These substrates are incompletely oxidized to acetate, coupled to sulfate reduction. Other suitable electron acceptors in addition to sulfate are thiosulfate and sulfite. Neither nitrate nor elemental sulfur are used as electron acceptors.

In the absence of an electron acceptor, $D$. nigrificans is able to grow by fermentation of fructose and pyruvate [7]. Additionally, D. nigrificans has been reported to grow with lactate and ethanol in syntrophic interaction with Methanobacterium thermoautotrophicum [5]. Syntrophic growth of D. carboxydivorans has never been tested. D. carboxydivorans is able to grow in the absence of an electron acceptor with CO $(100 \%)$, pyruvate, lactate, glucose and fructose [6]. The cellular fatty acid patterns of the two strains were analyzed by Parshina et al. [6] and Krishnamurthi et al. [8]. Both fatty acid patterns are similar and the dominating fatty acids were identified as 16:0, iso 15:0, iso 17:0, anteiso 15:0, 18:0 and iso 16:0. Collins and Widdel [9] analyzed the respiratory lipoquinone content of $D$. nigrificans DSM 574 and found MK7 as the predominant isoprenoid quinone. A summary of the classification and general features of $D$. nigrificans and D. carboxydivorans is presented in Table 1 and 2 , respectively.

\section{Genome sequencing and annotation}

\section{Genome project history}

D. nigrificans and D. carboxydivorans were selected for sequencing in the DOE Joint Genome Institute Community Sequencing Program 2009, proposal 300132_795700 'Exploring the genetic and physiological diversity of Desulfotomaculum species'. They are important for their position in sub- 
group a of the Desulfotomaculum cluster 1 . Sequencing the complete genome of the two strains was proposed as it would allow the study of the genetic and physiological diversity within subgroup a. Furthermore, a comparison of the two genomes should reveal the genes involved in $\mathrm{CO}$ metabolism and the $\mathrm{H}_{2}$ production in $D$. carboxydivorans. The genome projects of $D$. nigrificans and D. carboxydivorans are listed in the
Genome OnLine Database (GOLD) [23] as project Gi03933 and Gc01783, respectively. The two complete genome sequences were deposited in Genbank. Sequencing, finishing and annotation of the two genomes were performed by the DOE Joint Genome Institute (JGI). A summary of the project information of $D$. nigrificans and $D$. carboxydivorans is shown in Table 3.

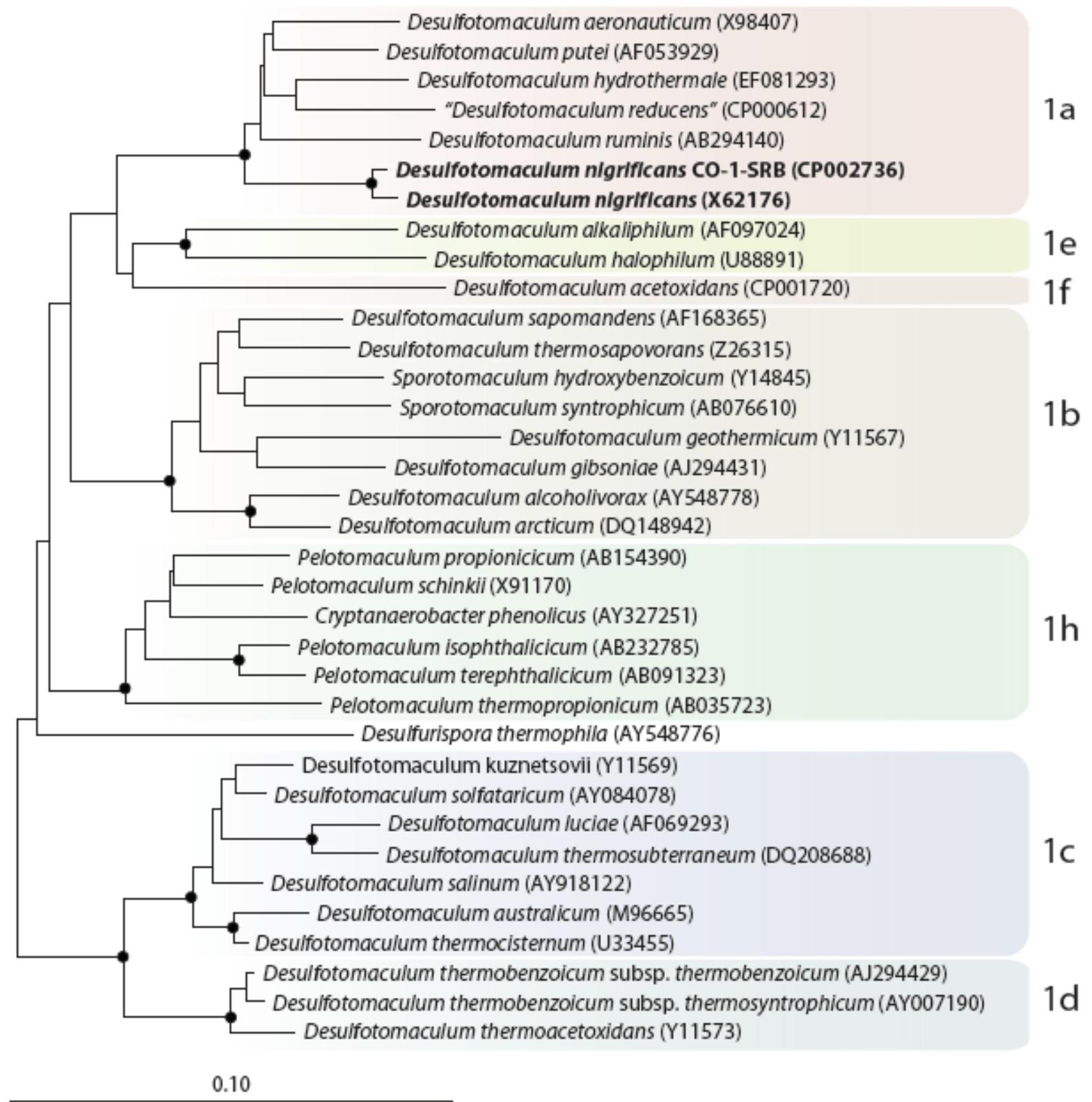

Figure 1. Neighbor joining tree based on $16 \mathrm{~S}$ rRNA sequences showing the phylogenetic affiliation of Desulfotomaculum and related species divided in the subgroups of Desulfotomaculum cluster 1. DSM 574 and DSM 14880 are in bold type. The sequences of different Thermotogales were used as outg roup, but were pruned from the tree. Closed circles represent bootstrap values between 75 and $100 \%$. The scale bar represents $10 \%$ sequence divergence. 
Table 1. Classification and general features of D. nigrificans DSM 574 according to the MIGS recommendations [10]

\begin{tabular}{|c|c|c|c|}
\hline MIGS ID & Property & Term & ${\text { Evidence } \operatorname{code} \mathrm{e}^{\mathrm{a}}}^{\mathrm{a}}$ \\
\hline & Current classification & $\begin{array}{l}\text { Domain Bacteria } \\
\text { Phylum Firmicutes } \\
\text { Class Clostridia } \\
\text { Order Clostridiales } \\
\text { Family Peptococcaceae } \\
\text { Genus Desulfotomaculum } \\
\text { Species Desulfotomaculum nigrificans } \\
\text { Type strain Delft } 74\end{array}$ & $\begin{array}{l}\text { TAS }[11] \\
\text { TAS }[12-14] \\
\text { TAS }[15,16] \\
\text { TAS }[17,18] \\
\text { TAS }[17,19] \\
\text { TAS }[17,20,21] \\
\text { TAS }[17,20] \\
\text { TAS }[12-14]\end{array}$ \\
\hline & Gram stain & negative, with a Gram-positive cell wall structure & \\
\hline & Cell shape & rods, rounded ends, sometimes paired & TAS [1] \\
\hline & Motility & Slight tumbling, peritrichous flagella & TAS [1] \\
\hline & Sporulation & oval, terminal or subterminal, slightly swelling the cell & TAS [1] \\
\hline & Temperature range & $30-70{ }^{\circ} \mathrm{C}$ & TAS [1] \\
\hline & Optimum temperature & $55^{\circ} \mathrm{C}$ & TAS [1] \\
\hline & Carbon source & glucose and other carbohydrates & TAS $[1,4,5]$ \\
\hline & Energy source & heterotrophic & TAS $[1,4,5]$ \\
\hline & Electron acceptor & sulfate, thiosulfate and sulfite. & TAS [4] \\
\hline MIGS-6 & Habitat & $\begin{array}{l}\text { soils, compost heaps, thermal spring } \\
\text { water, spoiled foods. }\end{array}$ & TAS [1] \\
\hline MIGS-6.3 & Salinity & not reported & \\
\hline MIGS-22 & Oxygen & obligate anaerobic & TAS [1] \\
\hline MIGS-15 & Biotic relationship & free living & TAS [1] \\
\hline MIGS-14 & Pathog enicity & none & TAS [1] \\
\hline MIGS-4 & Geographic location & Delft, The Netherlands & \\
\hline MIGS-5 & Sample collection time & & \\
\hline MIGS-4.1 & Latitude & 52.011 & \\
\hline MIGS-4.2 & Long itude & 4.360 & \\
\hline MIGS-4.3 & Depth & not reported & \\
\hline
\end{tabular}

Evidence codes - TAS: Traceable Author Statement (i.e., a direct report exists in the literature); NAS: Non-traceable Author Statement (i.e., not directly observed for the living, isolated sample, but based on a generally accepted property for the species, or anecdotal evidence). Evidence codes are from the Gene Ontology project [22]. 
Table 2. Classification and general features of D. carboxydivorans DSM 14880 according to the MIGS recommendations [10]

\begin{tabular}{|c|c|c|c|}
\hline MIGS ID & Property & Term & Evidence code $^{a}$ \\
\hline & & Domain Bacteria & TAS [11] \\
\hline & & Phylum Firmicutes & TAS [12-14] \\
\hline & & Class Clostridia & TAS $[15,16]$ \\
\hline & Current classification & Order Clostridiales & TAS $[17,18]$ \\
\hline & & Family Peptococcaceae & TAS $[17,19]$ \\
\hline & & Genus Desulfotomaculum & TAS $[17,20,21]$ \\
\hline & & Species Desulfotomaculum carboxydivorans & TAS $[17,20]$ \\
\hline & & Type strain CO-1-SRB & TAS [12-14] \\
\hline & Gram stain & negative, with a Gram-positive cell wall structure & TAS [6] \\
\hline & Cell shape & rods, rounded ends, sometimes paired. & TAS [6] \\
\hline & Motility & twisting and tumbling motion & TAS [6] \\
\hline & Sporulation & oval, terminal or subterminal & TAS [6] \\
\hline & Temperature range & $30-68^{\circ} \mathrm{C}$ & TAS [6] \\
\hline & Optimum temperature & $55^{\circ} \mathrm{C}$ & TAS [6] \\
\hline & Carbon source & $100 \%$ CO, with and without sulfate & TAS [6] \\
\hline & Energy source & hydrog enog enic and heterotrophic growth & TAS [6] \\
\hline & Electron acceptor & sulfate, thiosulfate and sulfite. & TAS [6] \\
\hline MIGS-6 & Habitat & Paper mill waste water sludge & \\
\hline MIGS-6.3 & Salinity & $0-17 \mathrm{~g} \mathrm{NaCl} \mathrm{I}^{-1}$ & TAS [6] \\
\hline MIGS-22 & Oxygen & oblig ate anaerobe & TAS [6] \\
\hline MIGS-15 & Biotic relationship & free living & TAS [6] \\
\hline MIGS-14 & Pathog enicity & none & \\
\hline MIGS-4 & Geographic location & Eerbeek, the Netherlands & TAS [6] \\
\hline MIGS-5 & Sample collection time & 1999 & TAS [6] \\
\hline MIGS-4.1 & Latitude & 52.104217 & TAS [6] \\
\hline MIGS-4.2 & Long itude & 6.060133 & TAS [6] \\
\hline MIGS-4. 3 & Depth & not reported & \\
\hline
\end{tabular}

Evidence codes - TAS: Traceable Author Statement (i.e., a direct report exists in the literature); NAS: Nontraceable Author Statement (i.e., not directly observed for the living, isolated sample, but based on a generally accepted property for the species, or anecdotal evidence). Evidence codes are from the Gene Ontology project [22]. 


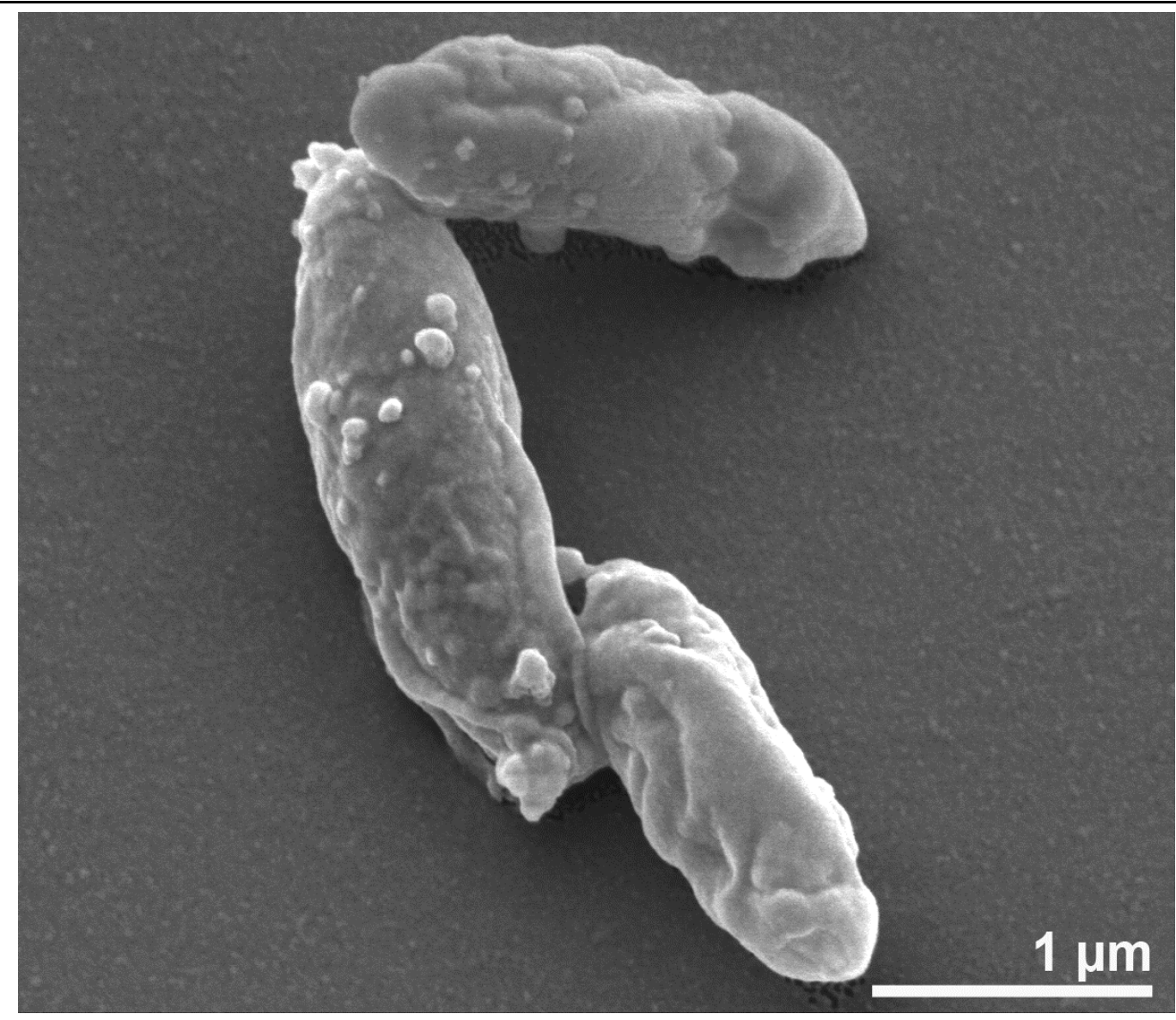

Figure 2. Scanning electron microscopic photog raph of DSM 574

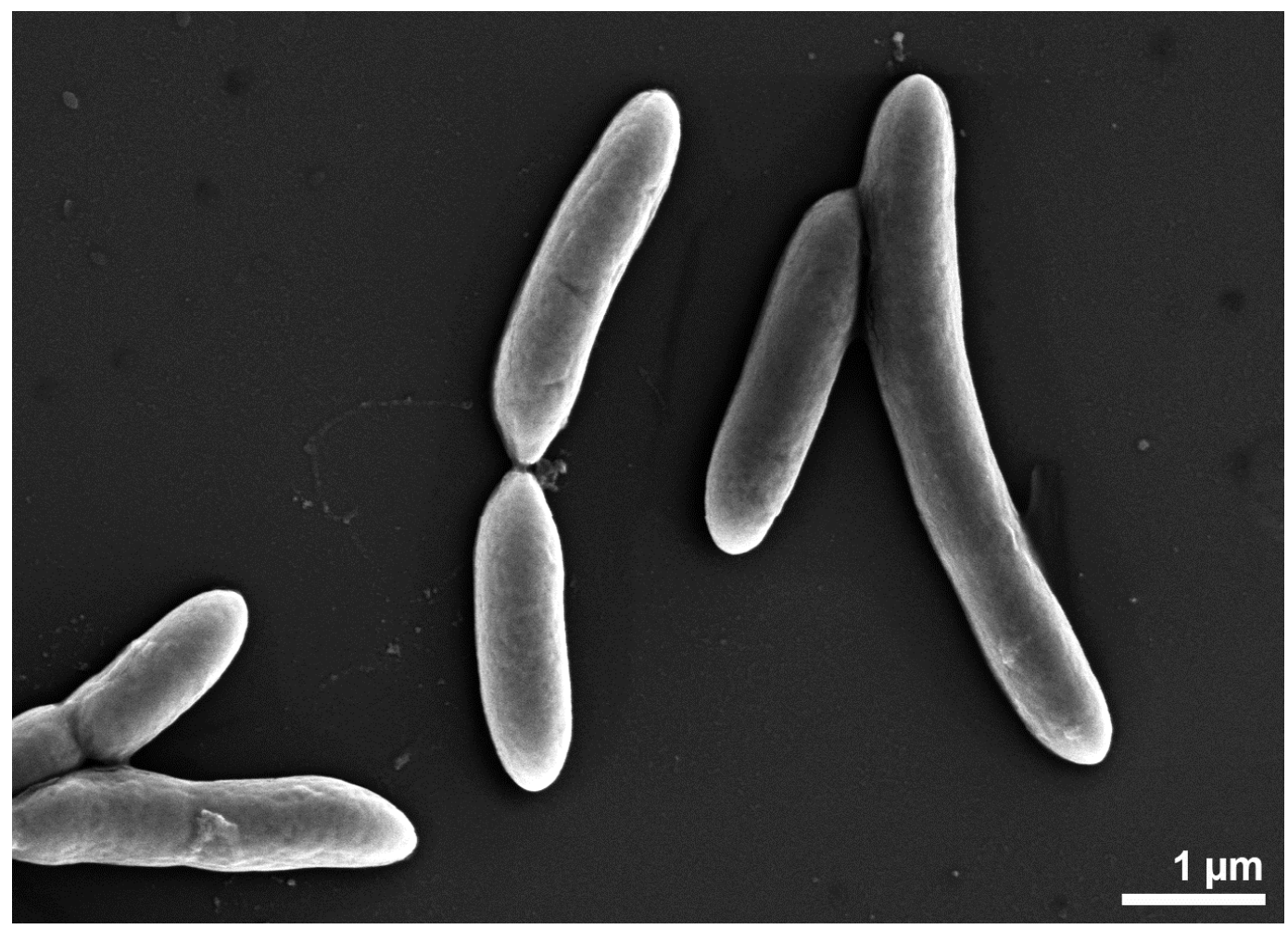

Figure 3. Scanning electron microscopic photog raph of DSM 14880 


\section{Growth conditions and DNA isolation}

$D$. nigrificans and D. carboxydivorans were grown anaerobically at $55^{\circ} \mathrm{C}$ in bicarbonate buffered medium with lactate and sulfate as substrates [6]. DNA of cell pellets was isolated using the standard DOE-JGI CTAB method recommended by the DOE Joint Genome Institute (JGI, Walnut Creek, CA, USA). Cells were resuspended in TE (10 mM tris; 1 mM EDTA, pH 8.0). Subsequently, cells were lysed using lysozyme and proteinase $\mathrm{K}$, and DNA was extracted and purified using CTAB and phe- nol:chloroform:isoamylalcohol extractions. After precipitation in 2-propanol and washing in 70\% ethanol, the DNA was resuspended in TE containing RNase. Following a quality and quantity check using agarose gel electrophoresis in the presence of ethidium bromide, and spectrophotometric measurement using a NanoDrop ND-1000 spectrophotometer (NanoDrop® Technologies, Wilmington, DE, USA).

Table 3. Genome sequencing project information of DSM 574 and DSM 14880.

\begin{tabular}{|c|c|c|c|}
\hline MIGS ID & Property & Term (for DSM 574) & Term (for DSM 14880) \\
\hline MIGS-31 & Finishing quality & Permanent draft & Finished \\
\hline MIGS-28 & Libraries used & $\begin{array}{l}\text { Three genomic libraries: } \\
454 \text { standard library, } 454 \text { PE } \\
\text { libraries ( } 7 \mathrm{~kb} \text { insert size), } \\
\text { one Illumina library }\end{array}$ & $\begin{array}{l}\text { Four genomic libraries: one } 454 \\
\text { pyrosequence standard library, two } \\
454 \text { PE libraries ( } 4 \mathrm{~kb} \text { and } 11 \mathrm{~kb} \text { insert } \\
\text { size), one Illumina library }\end{array}$ \\
\hline MIGS-29 & Sequencing platforms & $\begin{array}{l}\text { Illumina GAii, } 454 \text { GS FLX } \\
\text { Titanium }\end{array}$ & Illumina GAii, 454 GS FLX Titanium \\
\hline MIGS-31.2 & Fold coverage & $\begin{array}{l}462.8 \times \text { Illumina; } 35.2 \times \\
\text { pyrosequence }\end{array}$ & $\begin{array}{l}116.8 \times \text { Illumina; } 50.6 \times \\
\text { pyrosequence }\end{array}$ \\
\hline MIGS-30 & Assemblers & $\begin{array}{l}\text { Newbler version } 2.3- \\
\text { PreRelease-June } 30,2009, \\
\text { VELVET version } 1.0 .13, \\
\text { phrap version SPS - } 4.24\end{array}$ & $\begin{array}{l}\text { Newbler version } 2.3 \text {-PreRelease-June } \\
\text { 30, } 2009 \text {, VELVET version 1.0.13, } \\
\text { phrap version SPS - } 4.24\end{array}$ \\
\hline \multirow[t]{4}{*}{ MIGS-32 } & Gene calling method & Prodigal 1.4, GenePRIMP & Prodigal 1.4, GenePRIMP \\
\hline & INSDC ID & AEVP00000000 & СР002736.1 \\
\hline & Genome Database release & December 10, 2010 & Aug ust 13, 2012 \\
\hline & Genbank Date of Release & February 17, 2011 & May 23, 2011 \\
\hline \multirow[t]{4}{*}{ MIGS-13 } & GOLD ID & Gi03933 & Gc01783 \\
\hline & NCBI project ID & 46699 & 50757 \\
\hline & Source material identifier & $\operatorname{DSM} 574^{\top}$ & DSM $14880^{\top}$ \\
\hline & Project relevance & $\begin{array}{l}\text { Obtain insight into the phy- } \\
\text { logenetic and physiological } \\
\text { diversity of } \\
\text { Desulfotomacum species. }\end{array}$ & $\begin{array}{l}\text { Obtain insight into the phylog enetic } \\
\text { and physiolog ical diversity of } \\
\text { Desulfotomacum species, and } \\
\text { hydrog enog enic CO conversion. }\end{array}$ \\
\hline
\end{tabular}




\section{Genome sequencing and assembly}

The genome of $D$ nigrificans strain Delft 74 (DSM 574) was sequenced using a combination of Illumina and 454 sequencing platforms. All general aspects of library construction and sequencing can be found at the JGI website [24]. Pyrosequencing reads were assembled using the Newbler assembler (Roche). The initial Newbler assembly consisting of 75 contigs in two scaffolds was converted into a phrap [25] assembly by making fake reads from the consensus, to collect the read pairs in the 454 paired end library. Illumina GAii sequencing data $(3,053.3 \mathrm{Mb})$ was assembled with Velvet [26] and the consensus sequences were shredded into $1.5 \mathrm{~kb}$ overlapped fake reads and assembled together with the 454 data. The 454 draft assembly was based on $127.9 \mathrm{Mb} 454$ draft data and all of the 454 paired end data. Newbler parameters are -consed -a 50 -1 350 -g -m -ml 21. The Phred/Phrap/Consed software package [25] was used for sequence assembly and quality assessment in the subsequent finishing process. After the shotgun stage, reads were assembled with parallel phrap (High Performance Software, LLC). Whenever possible misassemblies were corrected with gapResolution [24], Dupfinisher [27], or sequencing cloned bridging PCR fragments with subcloning. Some gaps between contigs were closed by editing in Consed, by PCR and by Bubble PCR primer walks (J.-F. Chang, unpublished). Some mis-assembly is still possible in the current assembly that consists in seven contigs and one scaffold. A total of 268 additional reactions and one shatter library were necessary to close gaps and to raise the quality of the final contigs. Illumina reads were also used to correct potential base errors and increase consensus quality using a software Polisher developed at JGI [28]. The error rate of the final genome sequence is less than 1 in 100,000. Together, the combination of the Illumina and 454 sequencing platforms provided $498.0 \times$ coverage of the genome. The final assembly contained 332,256 pyrosequence and 37,872,777 Illumina reads.

The same protocol applied to the $D$. carboxydivorans strain C0-1-SRB (DSM 14880) genome allowed to produce finished assembly without gaps. Illumina GAii sequencing data $(334.0 \mathrm{Mb})$ was assembled with Velvet 0.7.63 and the 454 draft assembly was based on $138.8 \mathrm{MB}$ of sequence. A total of 290 additional reactions were necessary to close some gaps and to raise the quality of the final contigs. Illumina reads were also used to correct potential base errors and increase consensus quality using a software Polisher developed at JGI [28]. The error rate of the final genome sequence is less than 1 in 100,000 . Together, the combination of the Illumina and 454 sequencing platforms provided $167.4 \times$ coverage of the genome. The final assembly contained 543,495 pyrosequence and 9,254,176 Illumina reads

\section{Genome annotation}

Genes were identified using Prodigal [29] as part of the DOE-JGI genome annotation pipeline [30], followed by a round of manual curation using the JGI GenePRIMP pipeline [31]. The predicted CDSs were translated and used to search the National Center for Biotechnology Information (NCBI) nonredundant database, UniProt, TIGR-Fam, Pfam, PRIAM, KEGG, COG, and InterPro databases. Additional gene prediction analysis and functional annotation was performed within the Integrated Microbial Genomes - Expert Review (IMG-ER) platform [32].

\section{Genome properties}

The genome of $D$. nigrificans and $D$. carboxydivorans consist of one chromosome of $3,052,787$ and 2,892,255 nucleotides with a GC content of 46.28 and $46.63 \%$, respectively (Table $4)$. Of the 3,112 genes in the genome of $D$. nigrificans, 98 are RNA genes of which $616 \mathrm{~S}$ rRNA genes. A total of 2,340 genes of the 3,014 protein coding genes are assigned to COG functional categories. The distribution of these genes into COG functional categories is presented in Table 5. The distribution of the 2,174 COG assigned genes of $D$. carboxydivorans into COG functional categories is also presented in Table 5. Of the 2,844 predicted genes in the $D$. carboxydivorans genome, 2,747 are protein coding genes and 97 RNA genes, of which 8 are 16S rRNA genes. Both strains have sets of multiple 16S rRNA genes. Within the sets and among the sets most of the genes are 99.5-99.9\% identical. Each strain has one differently deviating $16 \mathrm{~S}$ rRNA gene, the difference probably originating from differential gene loss. In addition, 3.09\% of the total genes of $D$. carboxydivorans are identified as pseudo genes. More genome statistics of $D$. nigrificans and $D$. carboxydivorans are displayed in Table 4. 
Table 4. Genome statistics of DSM 574 (A) and DSM 14880 (B)

\begin{tabular}{|c|c|c|c|c|}
\hline \multirow[t]{2}{*}{ Attribute } & \multicolumn{2}{|c|}{ A. Genome (total) } & \multicolumn{2}{|c|}{ B. Genome (total) } \\
\hline & Value & $\%$ of total & Value & $\%$ of total \\
\hline Genome size (bp) & $3,052,787$ & 100 & $2,892,255$ & 100.00 \\
\hline DNA coding region (bp) & $2,595,629$ & 85.02 & 2457154 & 84.96 \\
\hline DNA G+C content (bp) & $1,412,511$ & 46.28 & $1,348,537$ & 46.63 \\
\hline Total genes & 3,112 & 100 & 2,844 & 100 \\
\hline RNA genes & 98 & 3.15 & 97 & 3.41 \\
\hline Protein-coding genes & 3,014 & 96.85 & 2,747 & 96.59 \\
\hline Genes in paralog clusters & 1,542 & 49.55 & 1,363 & 47.93 \\
\hline Genes assig ned to COGs & 2,340 & 75.19 & 2,174 & 76.44 \\
\hline Pseudo genes & 137 & 4.40 & 88 & 3.09 \\
\hline Genes with signal peptides & 582 & 18.70 & 504 & 17.72 \\
\hline Genes with transmembrane helices & 721 & 23.17 & 647 & 22.75 \\
\hline
\end{tabular}
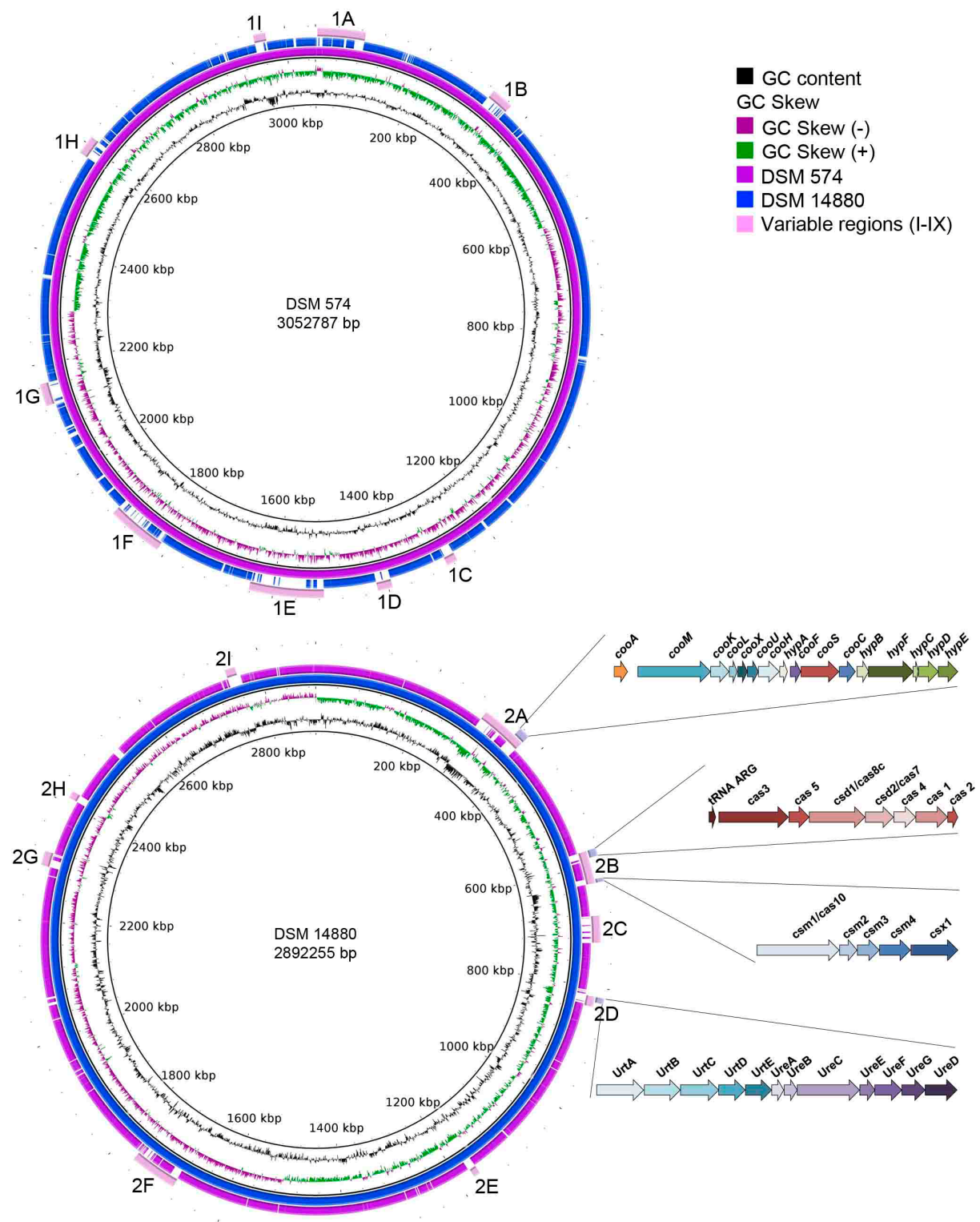

Figure 4. Graphical map of the DSM 574 (upper) and DSM 14880 (lower) chromosome. In both maps one genome was compared to the other. When genes were not similar or present in the other genome it resulted in gaps. The indicated variable regions with their function can also be found in Table 6 and the supplementary data S1. 
Table 5. Number of DSM 574 and DSM 14880 genes associated with the general COG functional categ ories.

\begin{tabular}{|c|c|c|c|c|c|}
\hline & & \multicolumn{2}{|c|}{ DSM 574} & \multicolumn{2}{|c|}{ DSM 14880} \\
\hline Code & Description & Value & $\% a g \mathrm{e}^{\mathrm{a}}$ & Value & $\% a g e^{a}$ \\
\hline$J$ & Translation & 153 & 5.97 & 152 & 3.39 \\
\hline A & RNA processing and modification & 1 & 0.04 & 0 & 0.00 \\
\hline K & Transcription & 153 & 5.97 & 139 & 5.85 \\
\hline $\mathrm{L}$ & Replication, recombination and repair & 210 & 8.20 & 172 & 7.23 \\
\hline B & Chromatin structure and dynamics & 1 & 0.04 & 1 & 0.04 \\
\hline $\mathrm{D}$ & Cell cycle control, mitosis and meiosis & 45 & 1.76 & 45 & 1.89 \\
\hline $\mathrm{Y}$ & Nuclear structure & 0 & 0.00 & 0 & 0.00 \\
\hline V & Defense mechanisms & 22 & 0.86 & 22 & 0.93 \\
\hline $\mathrm{T}$ & Signal transduction mechanisms & 171 & 6.71 & 148 & 6.22 \\
\hline M & Cell wall/membrane biog enesis & 132 & 5.15 & 126 & 5.3 \\
\hline $\mathrm{N}$ & Cell motility & 70 & 2.73 & 68 & 2.86 \\
\hline Z & Cytoskeleton & 0 & 0.00 & 0 & 0.00 \\
\hline W & Extracellular structures & 0 & 0.00 & 0 & 0.00 \\
\hline$U$ & Intracellular trafficking and secretion & 65 & 2.54 & 64 & 2.69 \\
\hline $\mathrm{O}$ & Posttranslational modification, protein turnover, chaperones & 83 & 3.24 & 85 & 3.57 \\
\hline $\mathrm{C}$ & Energy production and conversion & 217 & 8.47 & 211 & 8.87 \\
\hline G & Carbohydrate transport and metabolism & 125 & 4.88 & 98 & 4.12 \\
\hline $\mathrm{E}$ & Amino acid transport and metabolism & 224 & 8.74 & 216 & 9.08 \\
\hline $\mathrm{F}$ & Nucleotide transport and metabolism & 62 & 2.42 & 60 & 2.52 \\
\hline $\mathrm{H}$ & Coenzyme transport and metabolism & 134 & 5.23 & 133 & 5.59 \\
\hline I & Lipid transport and metabolism & 40 & 1.56 & 36 & 1.51 \\
\hline $\mathrm{P}$ & Inorganic ion transport and metabolism & 104 & 4.06 & 101 & 4.25 \\
\hline Q & Secondary metabolites biosynthesis, transport and catabolism & 29 & 1.13 & 27 & 1.14 \\
\hline $\mathrm{R}$ & General function prediction only & 261 & 10.19 & 250 & 10.51 \\
\hline S & Function unknown & 241 & 9.41 & 224 & 9.42 \\
\hline- & Not in COGs & 772 & 24.81 & 670 & 23.56 \\
\hline
\end{tabular}

a) The total is based on the total number of protein coding genes in the annotated genome. 
Table 6. Description of genes present in the variable regions depicted in Figure 4.

\section{Variable region Functions}

$1 \mathrm{~A}$

1B

$1 \mathrm{C}$

$1 \mathrm{D}$

$1 \mathrm{E}$

$1 \mathrm{~F}$

$1 \mathrm{G}$

$1 \mathrm{H}$

11

$2 \mathrm{~A}$

$2 \mathrm{~B}$

$2 \mathrm{C}$

$2 \mathrm{D}$

$2 \mathrm{E}$

$2 \mathrm{~F}$

$2 \mathrm{G}$

$2 \mathrm{H}$

21
Transposases, recombinases, transport proteins, isomerases, histidine kinase and threonine dehydrogenase

Transposases, recombinases, resolvase and alcohol dehydrog enase

Helicases, DNA-methylation, endonuclease and recombinase

TRAP transporter, Threonine dehydrogenase, 2 keto-4-petnenoate hydratase, sug ar kinase, aldolase, glycerol dehydrog enase and mannonate dehydratase

Pilus assembly, proteases and hypothetical proteins dominate this variable region

Protease, DNA methylase, RNA polymerase, recombinase, cytochrome c biogenesis, $\mathrm{Fe}^{2+}$ transport system and many hypothetical proteins

Transposase, secretory protein secB, nucleotide sug ar dehydrog enase, glycosyltransferase, sug ar epimerase, $\mathrm{O}$-antigen ligase and copper amine oxidase

Pyruvate ferredoxin oxidareductase, transport proteins, sugar phosphate permease, threonine dehydrogenase, transporsase, DNA methylase and endonuclease

Growth inhibitor protein, terminase, phage portal protein, secretory protein, recombinase and many hypothetical proteins

Endonuclease, DNA methylase, transposase, ATP binding protein, ATPase, threonine kinase, pyridoxamine 5'phosphate oxidase, ferric reductase, many hypothetical proteins and the CODH-ECH complex

\section{CRISPR-Cas}

DNA-helicases, -methyltransferase, and -replication protein, restriction protein and many hypothetical proteins

Urea metabolism

Mainly transport proteins and ag matinase

Alpha ribazole phosphatase, metal dependent phosphohydrolase, phenylacetate-CoA ligase, methyltransferase, amine oxidase, aldehyde dehydrog enase, transposase, phage tail component and many hypothetical proteins

Pilus associated proteins

Recombinase, integ rase, AAA ATPase, restriction modification system, deoxyribonuclease

Many transferase proteins 


\section{Insights into the genomes}

\section{Incomplete oxidation of organic compounds}

$D$. nigrificans and D. carboxydivorans oxidize organic substrates such as lactate, pyruvate, ethanol and sugars incompletely to acetate. Both genomes have gene copies that are predicted to encode Llactate dehydrogenases (DesniDRAFT_1264, 2906; Desca_0533) and D-lactate dehydrogenase (DesniDRAFT_0054, 1145, 1691; Desca_0863, 2222), which are involved in the oxidation of lactate to pyruvate. For incomplete oxidation of pyruvate to acetate via acetyl-CoA $D$. nigrificans and D. carboxydivorans have genes encoding a putative pyruvate dehydrogenase (DesniDRAFT_1250, 2504, 1245 and Desca_0770, 0146, 0775, respectively) and subsequently an acetyl-CoA synthetase (DesniDRAFT_2242 and Desca_0484, respectively). Although the two strains cannot grow with succinate, fumarate and malate as electron donors, genes to metabolize these compounds are present in both genomes. D. nigrificans and $D$. carboxydivorans have genes putatively coding for a fumarate reductase (DesniDRAFT_0617-15 and Desca_1387-89), fumarate hydratase (DesniDRAFT_0612-13 and Desca_1391-92), malate dehydrogenase (DesniDRAFT_0618 and Desca_1386), and a pyruvate carboxylase (DesniDRAFT_1477-78 and Desca_2116-17) that might be involved in the oxidation of succinate, fumarate and malate to pyruvate. For growth on ethanol, both genomes contain alcohol dehydrogenases (DesniDRAFT_0051, 0320, 0326, 0367, 1219, 2126, 2174, 2779; Desca_0375, 0418, 1671, $1913,1943,2553,2558$ ) and acetaldehyde dehydrogenases (DesniDRAFT_0038; Desca_1928).

For sulfate reducers to oxidize acetate to $\mathrm{CO}_{2}$, either the complete tricarboxylic acid (TCA) cycle or acetyl-CoA pathway has to be present [33]. Since $D$. nigrificans and $D$. carboxydivorans cannot grow with acetate, it was expected neither strain would possess a complete TCA cycle; which was verified by a lack of the putative genes that code for ATPdependent citrate synthase, aconitase, and isocitrate dehydrogenase. All genes coding for the acetyl-CoA pathway are present in both genomes, except for the genes encoding the acetyl-CoA synthase subunit and the FeS-protein large and small subunit. Probably the gene coding for the acetylCoA synthetase is also involved in the acetyl-CoA production from acetate and coenzyme A.

\section{Sugar metabolism}

D. nigrificans and D. carboxydivorans are able to utilize glucose and fructose as electron donors in the presence of sulfate. Additionally, both species are able to ferment fructose, although fermentation of glucose is only reported for $D$. carboxydivorans $[5,6]$. The capability of utilizing sugars for growth is unusual among Desulfotomaculum species. The other Desulfotomaculum species that belong to cluster I, sub group a, $D$. ruminis, $D$. aeronauticum, $D$. putei and $D$. hydrothermale (with the exception of " $D$. reducens"), are not able to grow with glucose or fructose [34-36]. Glucose metabolism in $D$. nigrificans was studied before [4]. Akagi and Jackson showed that the majority of the glucose was degraded by the Embden-Meyerhof-Parnas pathway and in several instances the glucose followed the Entner-Doudoroff pathway [4]. The EmbdenMeyerhof-Parnas pathway and the pentose phosphate pathway are predicted to be complete in the genome of $D$. nigrificans and $D$. carboxydivorans. However, genes coding for the 6phosphogluconate dehydratase and the 2-keto-3deoxy-6-phosphogluconate aldolase, the two characteristic enzymes of the Entner-Doudoroff pathway, were not found in the genome of $D$. nigrificans and D. carboxydivorans. A phosphotransferase system (PTS) for glucosespecific transport was not found in either genome. Such a system is present in the genome of the glucose-utilizer D. reducens (Dred_0332). Genes coding for the fructose-specific PTS are present in an operon structure in $D$. nigrificans (DesniDRAFT_2286 and 2291) and D. carboxydivorans (Desca_2698 and 2703). This system is likely involved in fructose uptake and its subsequent phosphorylation to fructose-1phosphate. The fructose-1-phosphate thus formed can be further phosphorylated by 1phosphofructokinase to fructose-1,6-bisphosphate (DesniDRAFT_2290 and Desca_2702).

Unlike D. nigrificans and D. carboxydivorans, $D$. ruminis and $D$. kuznetsovii are not able to grow with glucose or fructose. However, they have the genes that code for all the enzymes involved in the Embden-Meyerhof-Parnas pathway present in their genome. What is missing in their genome is the PTS for fructose-specific transport. This suggests that the absence of this PTS system prevents the use of fructose for growth. 


\section{Growth on one-carbon substrates}

$D$. nigrificans and D. carboxydivorans can grow with formate plus sulfate in the presence of yeast extract and acetate as a carbon source. Since the genomes lack a complete acetyl-CoA pathway, $D$. nigrificans and $D$. carboxydivorans are not able to produce acetyl-CoA from formate and need an additional carbon source. The two genomes have similar genes that putatively code for three formate dehydrogenases (FDHs). The first FDH consists of an alpha subunit (DesniDRAFT_0989, Desca_1018), which is located next to a hydrogenase (DesniDRAFT_0990, Desca_1017) and a flavoprotein (DesniDRAFT_0988 and Desca_1019). The flavoprotein has one predicted transmembrane helix. Therefore, these genes might code for one intracellular membrane associated FDH. The second FDH gene cluster (DesniDRAFT_1389-1392, Desca_2053-2055) putatively codes for a confurcating cytoplasmic FDH. The third is predicted to code for an extracellular FDH (DesniDRAFT_1396-1397, Desca_2059-2060) associated with the membrane by a proposed 10 transmembrane helixes containing protein (DesniDRAFT_1395, Desca_2058). BLAST results and orthologous BLAST analysis [37] indicate that this transmembrane helix protein is orthologous to cytochrome b. Therefore, electron transport from this FDH might go through cytochrome $b$.

D. nigrificans and D. carboxydivorans are able to grow with $\mathrm{CO}$ in the presence of yeast extract. However, D. nigrificans grows with up to $20 \%$ of CO coupled to sulfate reduction, while $D$. carboxydivorans can grow with $100 \%$ CO with and without sulfate. These physiological differences should also be visible in the genome for the genes involved with carbon monoxide dehydrogenase (CODH). Figure 5 shows the organization of the CODH catalytic subunit ( $\mathrm{cooS}$ ) and neighboring genes in $D$. nigrificans and $D$. carboxydivorans. $D$. nigrificans has two coos genes in the genome (DesniDRAFT_0854 and 1323) while $D$. carboxydivorans has three (Desca_0349, 1148, 1990). The organization of the $\operatorname{cooS}$ and neighboring genes in $D$. nigrificans is similar to that of two of the $\operatorname{cooS}$ and neighboring genes in $D$. carboxydivorans. However, one coos gene cluster in the D. carboxydivorans genome cannot be found in the genome of $D$. nigrificans. The genes in this cluster are similar to genes described to be involved in the $\mathrm{H}_{2}$ production from $\mathrm{CO}$ oxidation
[38-41]. Carboxydothermus hydrogenoformans was the first bacterium described to have multiple $\operatorname{cooS}$ genes, one of which is united in a cluster with hydrogenase genes [40]. The hydrogenase module of this gene cluster represents a membrane-bound energy-converting hydrogenase $(\mathrm{ECH})$ capable of energizing the membrane by proton translocation. Among sequenced Desulfotomaculum species, only $D$. carboxydivorans, $D$. acetoxidans, and D. ruminis possess putative genes coding for ECHs. However, in the latter two genomes, ECH encoding genes do not cluster with $\operatorname{coos}$ genes. Earlier analysis showed that clustering of cooS genes and ECH genes is a characteristic feature of hydrogenogenic carboxydotrophs [42]. The presence of the putative ECH-cooS gene cluster in D. carboxydivorans explains its ability to grow hydrogenogenically on CO.

In D. nigrificans there are no CODH involved genes in close proximity of the $\operatorname{coo} S$ genes, apart from one $\operatorname{coo} C$ gene (DesniDRAFT_0855). Apparently, this is sufficient for $D$. nigrificans to grow with $20 \%$ of CO coupled to sulfate reduction. However, D. ruminis, another Desulfotomaculum species in cluster 1a (Figure 1) of which the genome was recently described [43], also has the $\operatorname{coos}$ gene (Desru_0859) downstream of a transcriptional regulator (Desru_0858) and upstream of the cooC gene (Desru_0860) but that bacterium is not able to grow on $\mathrm{CO}$ and sulfate. The reason for this is not yet clear.

A cluster of nitrogenase genes (Dtox_1023 to 1030) has been described in the genome of Desulfotomaculum acetoxidans [44]. In the genomes of $D$. nigrificans and D. carboxydivorans very similar gene clusters occur (DesniDRAFT_0869-0858 and Desca_1134-1144). Notably, in both cases there are cooS genes in the vicinity (DesniDRAFT_0854 and Desca_1148). They are located on another DNA strand and are convergently directed. Since the low-potential carbon monoxide seems to be a good electron donor for nitrogen fixation, this proximity might be more than mere coincidence. This would suggest that small amounts of CO could be oxidized by $D$. nigrificans in the absence of sulfate. D. ruminis also has a similar gene cluster (Desru_3454-3445). However, in contrast to the genomes of $D$. nigrificans and $D$. carboxydivorans no cooS gene is nearby in the genome of $D$. ruminis. 
A

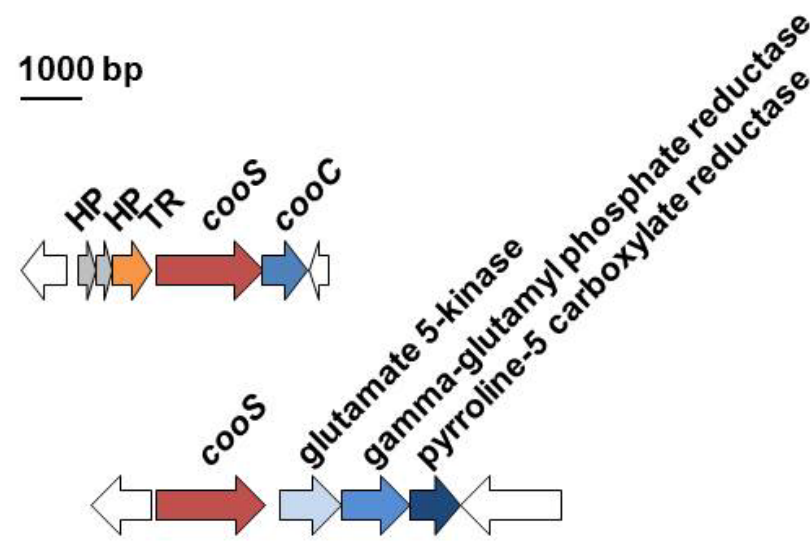

DesniDRAFT_1323-1326

DesniDRAFT_0851-0855

B $1000 \mathrm{bp}$

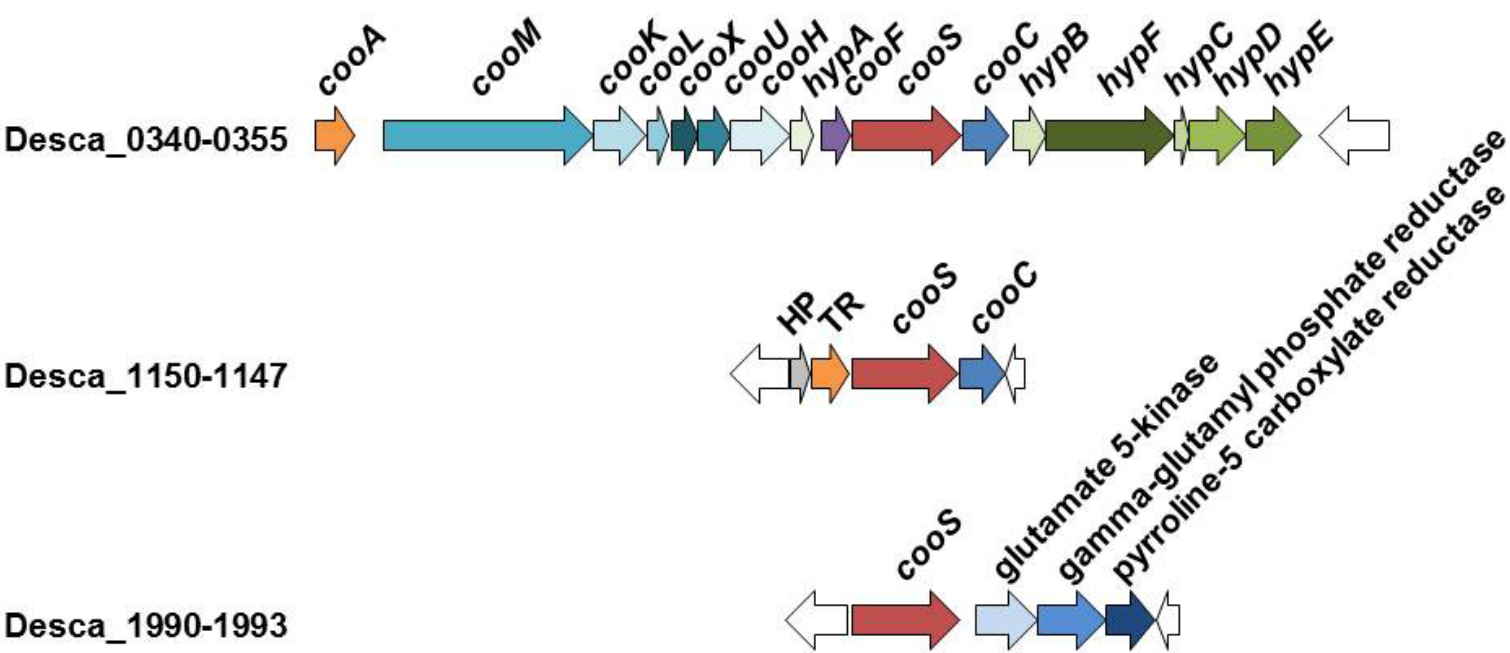

Figure 5. Organization of $\operatorname{cooS}$ and neighboring genes in DSM 574 (A) and DSM 14880 (B). Abbreviations: $\mathrm{HP}$, hypothetical protein; TR, transcriptional regulator.

Methyltransferase genes as present in $D$. kuznetsovii that might point to possible growth with methanol or methylated amines were not found in the genomes of $D$. nigrificans and $D$. carboxydivorans. These two strains accordingly, do not grow with methanol. Growth on methylated amines were never tested, but the genome suggests there is no growth possible with these compounds.

\section{Hydrogen metabolism}

$D$. nigrificans and $D$. carboxydivorans have a similar hydrogenase composition that is dominated by [FeFe] hydrogenases, as observed in other Desulfotomaculum spp. Each of the two bacteria has 9 [FeFe] hydrogenases, divided in the following groups: Three copies of trimeric bifurcating hydrogenases

(DesniDRAFT_0775-0777, DesniDRAFT_0770-0772 and DesniDRAFT_13311333; Desca_1224-1226, Desca_1230-1232 and Desca_1996-1998); two copies of a monomeric hydrogenase (DesniDRAFT_0646 and DesniDRAFT_0308; Desca_1356 and Desca_1680); one HsfB-type hydrogenase encoding a PASsensing domain that is likely involved in sensing and regulation (DesniDRAFT_0986 and Desca_1021); one hydrogenase that is part of a 5gene operon also encoding one membrane protein and two flavin-dependent oxidoreductases (DesniDRAFT_1073-1077 and Desca_0931-0935); and finally two copies of a membrane-associated hydrogenase (DesniDRAFT_1068-1070 and DesniDRAFT_2001-2003; Desca_0940-0938 and Desca_2453-2455). The catalytic subunit 
Visser et al.

(DesniDRAFT_1068, 2001 and Desca_0940, 2453) of this hydrogenase contains a tat signal motif, which suggests that the hydrogenase complex is positioned extracellular. Moreover, the membrane associated subunit is a 10 transmembrane helix containing protein that is orthologous to cytochrome b. This is similar to the extracellular FDH.

The high number of hydrogenases in the genomes of the two bacteria indicate a high metabolic flexibility. This is important for changing growth strategies, from, for example, sulfate respiration to syntrophic growth. A syntrophic co-culture of $D$. nigrificans and Methanobacterium thermoautotrophicum on lactate and ethanol was described [5]. Syntrophic consortia are able to grow from very small free energy changes due to their ability to overcome thermodynamically difficult reactions. Reverse electron transfer is an essential part of this. The genes coding for the bifurcating hydrogenases and the confurcating formate dehydrogenase in the $D$. nigrificans genome are therefore likely candidates to be involved in syntrophic growth on lactate and ethanol.

A membrane-associated ECH is present only in $D$. carboxydivorans, as mentioned above, and no other [NiFe] hydrogenases are present. Other membrane associated complexes found in the genome of D. nigrificans and D. carboxydivorans are complex I (DesniDRAFT_0902-0892 and Desca_11101120 ) and a $\mathrm{H}^{+}$-pumping membrane-bound pyrophosphatase (DesniDRAFT_2060 and Desca_2506).

\section{Electron acceptor metabolism}

The genes for the assimilatory sulfate reduction are organized in an identical way in D. nigrificans and D. carboxydivorans. ATP-sulfurylase (DesniDRAFT_1837, Desca_2237) is followed by adenosine- 5 '-phosphosulfate (APS) reductase (DesniDRAFT_1836-1835, Desca_2378-2377), and the QmoAB complex (DesniDRAFT_1834-1833, Desca_ 2376-2375). A qmoC gene is absent but seems to be substituted by heterodisulfide reductases (Hdr) CB (DesniDRAFT _1838-1839, Desca_ 2381-2380). This organization is also found in $D$. ruminis and $D$. reducens. The position of the HdrCB is switched to the other side in $D$. acetoxidans, D. gibsoniae, D. alcoholicoviorans, Desulfurispora thermophila, and Desulfarculus baarsii (which owns a Gram-positive aprBA [45]). In contrast to these organisms, D. kuznetsovii, Ammonifex degensii, Desulfovirgula thermocuniculi, and Gram-negative sulfate-reducing bacteria which posses a Gram-positive aprBA [45] like Desulfomonile tiedjei and Syntrophobacter fumaroxidans have a complete qmoABC complex (for D. kuznetsovii: Desku_ 1075, Desku_1076, Desku_1078).

The genes for the dissimilatory sulfite reductase found and their organization are identical to all other six Desulfotomaculum genomes published so far and most other Gram-positive sulfate-reducing bacteria. The dsrAB genes (DesniDRAFT_22562255, Desca_2666-2665) are linked to a dsrD gene (DesniDRAFT_2254, Desca_2664). Both organisms also contain a truncated DsrMK complex [46](DesniDRAFT_2267-2268, Desca_2678-2679) which is linked to a dsrC gene (DesniDRAFT_2266, Desca_2677) as it was found in D. ruminis [43]. This truncated DsrMK is generally found in Grampositive sulfate-reducing bacteria and not restricted to members of the genus Desulfotomaculum.

D. nigrificans and D. carboxydivorans lack nitrate reduction genes for reduction of nitrate to $\mathrm{N}_{2}$. $\mathrm{Ni}$ trate reductase, nitric-oxide forming nitrite reductase, nitric-oxide reductase and nitrousoxide reductase are all absent in both genomes. However, a nitrite/sulphite reductase (DesniDRAFT_1001, 2506; Desca_0162, 1181) and an ammonia forming nitrite reductase (DesniDRAFT_0204; Desca_2313) are present in the genome of $D$. nigrificans and $D$. carboxydivorans. No taurine degradation pathway was detected in the genome of either strain, but it was described for the closely related $D$. ruminis [43].

\section{Fumarate reductases}

Using fumarate as an electron acceptor for growth of $D$. nigrificans and D. carboxydivorans has not been tested yet. However, a fumarate reductase is present in the genomes of the two bacteria. The three genes encode for a FAD containing catalytic subunit (DesniDRAFT_0617; Desca_1387), an iron sulfur containing subunit (DesniDRAFT_0616; Desca_1388), and a membrane associated cytochrome b (DesniDRAFT_0615 and Desca_1389). This cytochrome $b$ protein might perform an electron interaction with the cytochrome $b$ of the extracellular FDH (Figure 6, panel B). This interaction could occur as described in Wolinella succinogenes, where fumarate can be used as an electron acceptor for growth on formate [47]. 


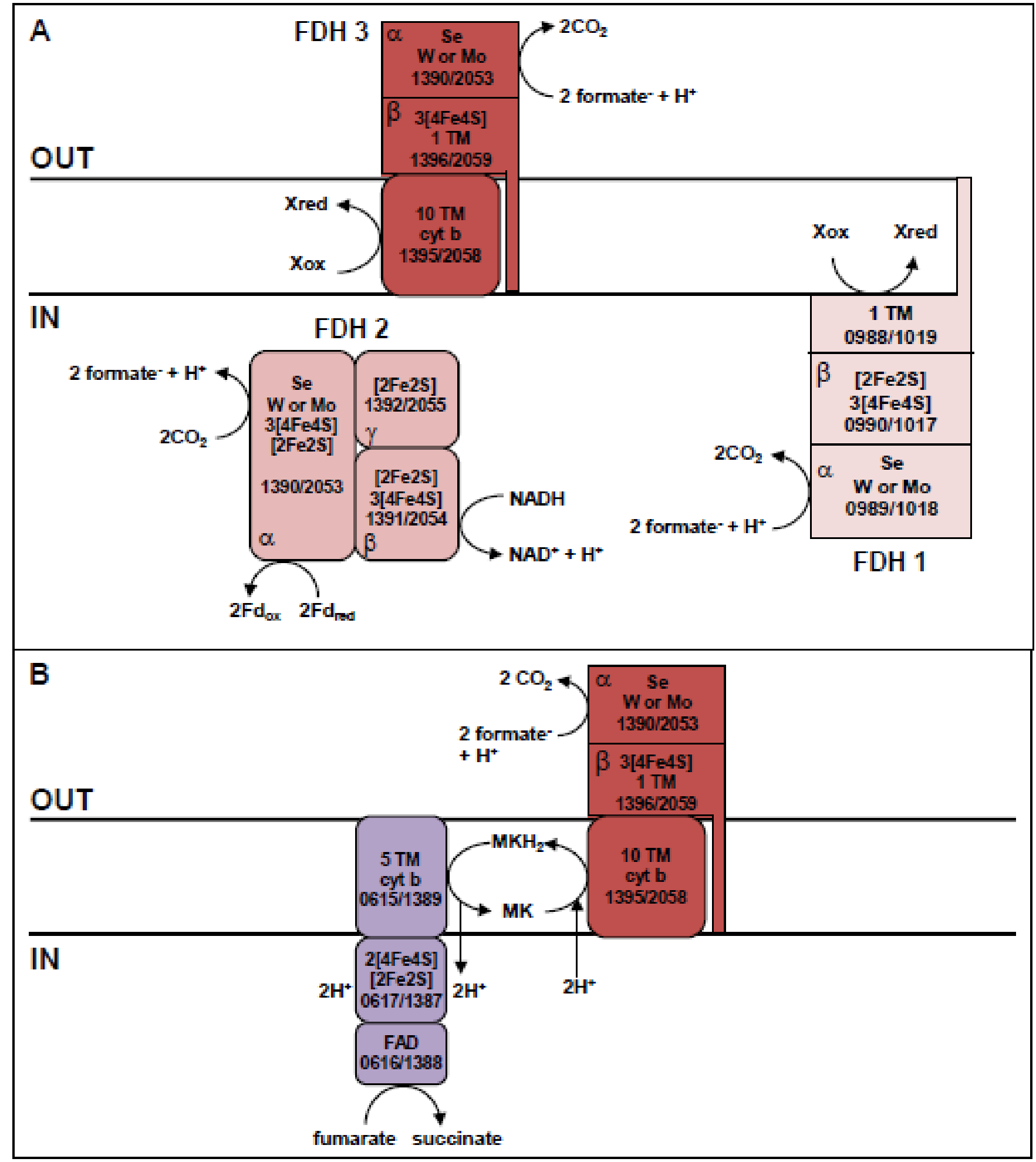

Figure 6. Schematic representation of putative formate dehydrogenases in the genome of DSM 574 and DSM 14880 (A). Including the hypothesized electron interaction of the putative extracellular membrane bound formate dehydrog enase with the putative fumarate reductase (B). The electron acceptor fumarate is reduced to succinate by using formate as an electron donor. Gene locus tag numbers and -, $\beta$, and $ү$ subunits are depicted. Moreover, predicted iron-sulfur clusters and other metal-binding sites are indicated. 


\section{Comparative genomics}

Distinct genes in Desulfotomaculum carboxydivorans and $D$. nigrificans

To reveal genomic differences between these two very closely related species, a bidirectional BLAST of the protein coding genes was performed. BLAST analyses were performed using standard settings and best hits were filtered for $70 \%$ sequence coverage and $40 \%$ identity (supplementary data S1). A total of 2,529 homologous genes were found (Figure 7). The distinct genes were screened for operon structure and function, revealing genes involved in CRISPR, urea metabolism and hydrogenogenic CO metabolism in $D$. carboxydivorans.

CRISPR genes in D. carboxydivorans were found to have low sequence coverage and or identity with genes in the D. nigrificans genome (Figure 3 ). These genes involved two CRISPR-Cas systems, which we classified as a I-C subtype (Desca_0534-0540) and a III-A subtype (Desca_0572-0576). D. nigrificans has one CRISPR-Cas system subtype, IA (DesniDRAFT_2444-2452), which is also present in D. carboxydivorans (Desca_0726-0734). The presence of multiple CRISPR-Cas systems and the occurrence of the different subtypes in one strain has been described previously $[49,50]$ and shows that the co-occurrence of subtype I-A with I-C and III-A is a common feature. However, it also shows that $D$. carboxydivorans is part of the $2 \%$ of bacteria that have a III-A subtype without a III-B subtype.

The genome of $D$. carboxydivorans also contains genes coding for a urease (Desca_0743-0749) and urea transport (Desca_0738-0742) (Figure 3). Urease catalyzes the reaction of urea to $\mathrm{CO}_{2}$ and ammonia. Urea is very common in the environment and is a nitrogen source for many bacteria [51]. The genome of $D$. nigrificans lacks the genes coding for an urease, which indicates that $D$. nigrificans is relatively more restricted regarding its nitrogen source. Other interesting genes that are present in the $D$. carboxydivorans genome and not in the $D$. nigrificans genome are genes involved in the carbon monoxide dehydrogenase (CODH) and hydrogenase as described above.

DSM 574 (3014)

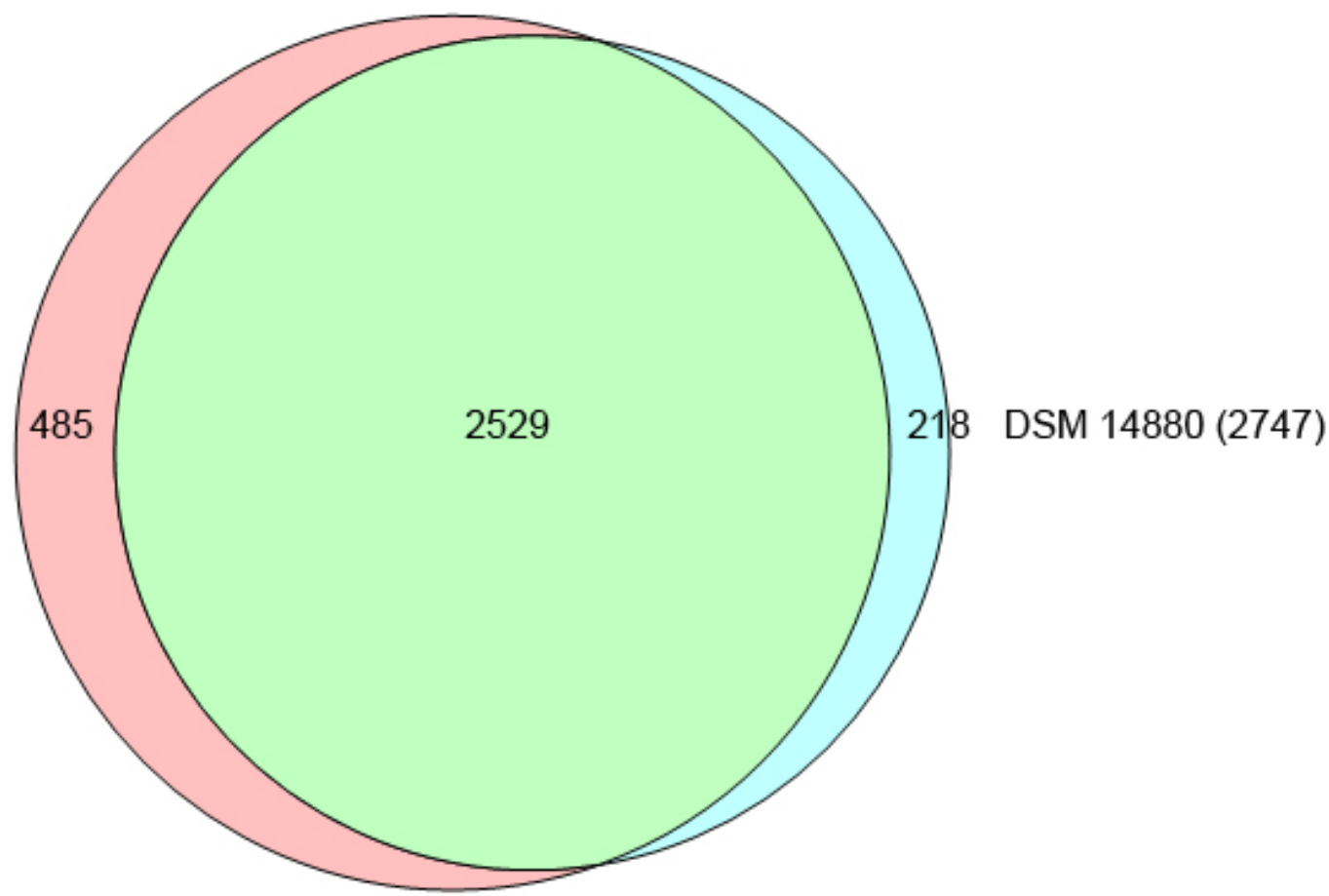

Figure 7. Venn diagram showing a comparison of the protein coding genes of DSM 574 and DSM 14880 . The number of overlapping protein coding genes is given inside the areas of the circles and the total number of derived protein sequences used for each strain is shown in parentheses. The figure was created using the prog ram Venn diagram plotter available from the Pacific Northwest National Laboratory Software Distribution Center [48]. 


\section{Taxonomic conclusions}

The overall similarity of the genome sequences of the type strains of $D$. nigrificans and $D$. carboxydivorans was estimated by using the Genome-To-Genome Distance Calculator (GGDC) as described previously [52]. This program calculates DNA-DNA similarity values by comparing the genomes to obtain high-scoring segment pairs (HSPs) and inferring distances from a set of three formulas (1, HSP length/total length; 2, identities/HSP length; 3, identities/total length). According to the GGDC the average estimated DNADNA similarity value between the two type strains is $86.5 \pm 5.5 \%$ and thus clearly above $70 \%$, which is the widely accepted threshold value for assigning strains to the same species [53]. The high similarity of the genome sequences of both type strains was further supported by the average nucleotide identity of shared genes (ANI), which proved to be above $99 \%$. This ANI value is much higher than the 95 to $96 \%$ value shown to correspond to the 70\% DNA-DNA hybridization level [54]. Moreover, the two strains have almost identical 16S rRNA gene sequences (>99\%) and a high number of shared genes (Figure 7). It should be mentioned that the previously reported and deposited rRNA gene sequence of $D$. nigrificans DSM 574 contained a lot ambiguities and some missing nucleotides, which are counted as mismatches by BLAST. Therefore, we reanalyzed the rRNA gene sequences of D. nigrificans deposited in the NCIMB culture collections and confirmed the identity of the rRNA gene sequence found in the genome of DSM 574. We propose that the species should be united under one name. According to the rules of priority as given by the Bacteriological Code [55] the name $D$. nigrificans should be used for the unified taxon, with $D$. carboxydivorans as a later heterotypic synonym.

\section{Acknowledgements}

We would like to gratefully acknowledge the help of Christine Munk and Megan Lu for finishing the genome sequence (both at JGI). The work conducted by the U.S. Department of Energy Joint Genome Institute is supported by the Office of Science of the U.S. Department

\section{References}

1. Campbell LL, Postgate JR. Classification of the spore-forming sulfate-reducing bacteria. Bacteriol Rev 1965; 29:359-363. PubMed

\section{Emended description of \\ Desulfotomaculum nigrificans (Werkman and Weaver 1927) Camp- bell and Postgate 1965}

The description is as given by Campbell and Postgate [1] and Parshina et al. [6] with the following modifications.

The cells are Gram-positive, rod-shaped with rounded ends, $0.3-1.5 \times 2-15 \mu \mathrm{m}$, single or sometimes paired. Motility with tumbling or twisting movements conferred by peritrichous flagella. Terminal or subterminal oval endospores that are slightly swelling the cells. Thermophilic and neutrophilic with an temperature optimum of $55^{\circ} \mathrm{C}$. $\mathrm{NaCl}$ is not required for growth. The following substrates are utilized, coupled to the reduction of sulfate to sulfide: DL-lactate, pyruvate, ethanol, L-alanine, D-fructose, D-glucose. Acetate and methanol are not utilized. Substrates are incompletely oxidized to acetate. In the presence of 0.5 $\mathrm{g} / \mathrm{l}$ yeast extract, lithoheterotrophic growth is possible, such as growth on $\mathrm{H}_{2}$ and $\mathrm{CO}_{2}$ with sulfate or growth on $20 \%$ CO with sulfate for $D$. nigrificans strain Delft 74 and growth on $100 \%$ CO with or without sulfate for strain CO-1-SRB. Suitable electron acceptors with lactate as substrate are sulfate, sulfite and thiosulfate, but not elemental sulfur or nitrate. Fermentation of pyruvate and fructose; strain CO-1-SRB is also able to ferment DL-lactate, glucose and CO. The prevalent respiratory lipoquinone is MK7 with only small amounts of MK6. The dominating cytochromes are of type $b$. Major cellular fatty acids are 16:0, iso $15: 0$, iso $17: 0$, anteiso $15: 0,18: 0$ and iso $16: 0$. The DNA G+C content is around $46 \mathrm{~mol} \%$. The type strain is Delft 74 (=NCIMB $8395=$ DSM $574=$ ATCC $19998=$ NBRC 13698).

of Energy under Contract No. DE-AC02-05CH11231, and was also supported by grants CW-TOP 700.55.343 and ALW 819.02.014 of the Netherlands Science Foundation (NWO) and grant 323009 of the European Research Council. 
3. Starkey RL. A study of spore formation and other morphological characteristics of Vibrio desulfuricans. Arch Mikrobiol 1938; 9:268-404. http://dx.doi.org/10.1007/BF00407364

4. Akagi JM, Jackson G. Deg radation of glucose by proliferating cells of Desulfotomaculum nigrificans. Appl Microbiol 1967; 15:1427-1430. $\underline{\text { PubMed }}$

5. Klemps R, Cypionka H, Widdel F, Norbert P. Growth with hydrogen, and further physiological characteristics of Desulfotomaculum species. Arch Microbiol 1985; 143:203-208. http://dx.doi.org/10.1007/BF00411048

6. Parshina SN, Sipma J, Nakashimada $Y$, Henstra AM, Smidt H, Lysenko AM, Lens PN, Letting a G, Stams AJ. Desulfotomaculum carboxydivorans sp. nov., a novel sulfate-reducing bacterium capable of growth at $100 \%$ CO. Int I Syst Evol Microbiol 2005; 55:2159-2165. PubMed http://dx.doi.org/10.1099/ijs.0.63780-0

7. Postgate JR. Sulfate-Free Growth of Clostridium nigrificans. J Bacteriol 1963; 85:1450-1451. PubMed

8. Krishnamurthi S, Spring $S$, Anil Kumar P, Mayilraj S, Klenk HP, Suresh K. Desulfotomaculum defluvii sp. nov., a sulfate-reducing bacterium isolated from the subsurface environment of a landfill. Int J Syst Evol Microbiol 2012. PubMed

9. Collins M, Weddel F. Respiratory quinones of sulphate-reducing and sulphur-reducing bacteria: a systematic investigation. Syst App/ Microbiol 1986; 8:8-18. http://dx.doi.org/10.1016/S07232020(86)80141-2

10. Field D, Garrity G, Gray T, Morrison N, Seleng ut J, Sterk P, Tatusova T, Thomson N, Allen MJ, Angiuoli SV, et al. The minimum information about a genome sequence (MIGS) specification. Nat Biotechnol 2008; 26:541-547. PubMed http://dx.doi.org/10.1038/nbt1360

11. Woese CR, Kandler O, Wheelis ML. Towards a natural system of org anisms: proposal for the domains Archaea, Bacteria, and Eucarya. Proc Natl Acad Sci USA 1990; 87:4576-4579. PubMed http://dx.doi.org/10.1073/pnas.87.12.4576

12. Gibbons NE, Murray RGE. Proposals Concerning the Higher Taxa of Bacteria. Int I Syst Bacteriol 1978; 28:1-6. http://dx.doi.org/10.1099/00207713-28-1-1

13. Garrity GM, Holt JG. The Road Map to the Manual. In: Garrity GM, Boone DR, Castenholz RW (eds), Bergey's Manual of Systematic Bacteriolo- gy, Second Edition, Volume 1, Springer, New York, 2001, p. 119-169.

14. Murray RGE. The Higher Taxa, or, a Place for Everything...? In: Holt JG (ed), Bergey's Manual of Systematic Bacteriology, First Edition, Volume 1, The Williams and Wilkins Co., Baltimore, 1984, p. 31-34.

15. List Editor. List of new names and new combinations previously effectively, but not validly, published. List no. 132. Int I Syst Evol Microbiol 2010; 60:469-472. http://dx.doi.org/10.1099/ijs.0.022855-0

16. Rainey FA. Class II. Clostridia class nov. In: De Vos P, Garrity G, Jones D, Krieg NR, Ludwig W, Rainey FA, Schleifer KH, Whitman WB (eds), Bergey's Manual of Systematic Bacteriology, Second Edition, Volume 3, Spring er-Verlag, New York, 2009, p. 736.

17. Skerman VBD, McGowan V, Sneath PHA. Approved Lists of Bacterial Names. Int J Syst

Bacteriol 1980; 30:225-420. http://dx.doi.org/10.1099/00207713-30-1-225

18. Prévot AR. In: Hauderoy P, Ehringer G, Guillot G, Magrou. J., Prévot AR, Rosset D, Urbain A (eds), Dictionnaire des Bactéries Pathogènes, Second Edition, Masson et Cie, Paris, 1953, p. 1-692.

19. Rogosa M. Peptococcaceae, a new family to include the Gram-positive, anaerobic cocci of the genera Peptococcus, Peptostreptococcus and Ruminococcus. Int J Syst Bacteriol 1971; 21:234237. http://dx.doi.org/10.1099/00207713-21-3$\underline{234}$

20. Campbell LL, Postgate JR. Classification of the spore-forming sulfate-reducing bacteria. Bacteriol Rev 1965; 29:359-363. PubMed

21. Campbell LL. Genus IV. Desulfotomaculum Campbell and Postg ate 1965, 361. In: Buchanan RE, Gibbons NE (eds), Bergey's Manual of Determinative Bacteriology, Eighth Edition, The Williams and Wilkins Co., Baltimore, 1974, p. 572 573.

22. Ashburner M, Ball CA, Blake JA, Botstein D, Butler H, Cherry JM, Davis AP, Dolinski K, Dwight SS, Eppig JT, et al. Gene ontology: tool for the unification of biology. The Gene Ontology Consortium. Nat Genet 2000; 25:25-29. PubMed http://dx.doi.org/10.1038/75556

23. Pagani I, Liolios K, Jansson J, Chen IM, Smirnova T, Nosrat B, Markowitz VM, Kyrpides NC. The Genomes OnLine Database (GOLD) v.4: status of genomic and metagenomic projects and their as- 
sociated metadata. Nucleic Acids Res 2012;

40:D571-D579. PubMed

http://dx.doi.org/10.1093/nar/gkr1100

24. JGI website. http://www.jgi.doe.gov/.

25. The Phred/Phrap/Consed software package. http://www.phrap.com.

26. Zerbino DR, Birney E. Velvet: algorithms for de novo short read assembly using de Bruijn graphs. Genome Res 2008; 18:821-829. PubMed http://dx.doi.org/10.1101/gr.074492.107

27. Han $C$, Chain P. Finishing repeat regions automatically with Dupfinisher. In: H.R. A, H. V, editors2 006 June 26-29, 2006. CSREA Press. p 1416.

28. Lapidus A, LaButti K, Foster B, Lowry S, Trong S, Goltsman E. POLISHER: An effective tool for using ultra short reads in microbial genome assembly and finishing. Marco Island, FL: AGBT; 2008.

29. Hyatt D, Chen GL, Locascio PF, Land ML, Larimer FW, Hauser LJ. Prodigal: prokaryotic gene recognition and translation initiation site identification. BMC Bioinformatics 2010; 11:119. PubMed http://dx.doi.org/10.1186/1471-2105-11-119

30. Mavromatis K, Ivanova NN, Chen IM, Szeto E, Markowitz VM, Kyrpides NC. The DOE-JGl Standard operating procedure for the annotations of microbial genomes. Stand Genom ic Sci 2009; 1:63-67. PubMed http://dx.doi.org/10.4056/sigs.632

31. Pati A, Ivanova NN, Mikhailova N, Ovchinnikova G, Hooper SD, Lykidis A, Kypides NC.

GenePRIMP: a gene prediction improvement pipeline for prokaryotic genomes. Nat Methods 2010; 7:455-457. PubMed http://dx.doi.org/10.1038/nmeth.1457

32. Markowitz VM, Mavromatis K, Ivanova NN, Chen IM, Chu K, Kyrpides NC. IMG ER: a system for microbial genome annotation expert review and curation. Bioinformatics 2009; 25:2271-2278. $\underline{\text { PubMed }}$ http://dx.doi.org/10.1093/bioinformatics/btp393

33. Goevert D, Conrad R. Carbon isotope fractionation by sulfate-reducing bacteria using different pathways for the oxidation of acetate. Environ Sci Technol 2008; 42:7813-7817. PubMed http://dx.doi.org/10.1021/es800308z

34. Hagenauer A, Hippe $H$, Rainey FA. Desulfotomaculum aeronautic um sp. nov., a Sporeforming, Thiosulfate-Reducing Bacterium from Corroded Aluminium Alloy in an Aircraft. Syst Appl Microbiol 1997; 20:65-71.
http://dx.doi.org/10.1016/S072 3-2020(97)80049$\underline{5}$

35. Haouari O, Fardeau ML, Cayol JL, Casiot C, Elbaz-Poulichet F, Hamdi M, Joseph M, Ollivier B. Desulfotomaculum hydrothermale sp. nov., a thermophilic sulfate-reducing bacterium isolated from a terrestrial Tunisian hot spring. Int J Syst Evol Microbiol 2008; 58:2 529-2 535. PubMed http://dx.doi.org/10.1099/ijs.0.65339-0

36. Liu Y, Karnauchow TM, Jarrell KF, Balkwill DL, Drake GR, Ring elberg D, Clarno R, Boone DR. Description of two new thermophilic Desulfotomaculum spp., Desulfotomaculum putei sp. nov., from a deep terrestrial subsurface, and Desulfotomaculum luciae sp. nov., from a hot spring. Int J Syst Bacteriol 1997; 47:61 5-621. http://dx.doi.org/10.1099/00207713-47-3-615

37. Zhou Y, Landweber LF. BLASTO: a tool for searching ortholog ous groups. Nucleic Acids Res 2007; 35(Web Server issue):W678-82.

38. Hedderich R. Energy-converting [NiFe] hydrogenases from archaea and extremophiles: ancestors of complex I. J Bioenerg B iomembr 2004; 36:65-75. PubMed http://dx.doi.org/10.1023/B:JOBB.0000019599.43 $\underline{969.33}$

39. Meuer J, Bartoschek S, Koch J, Kunkel A, Hedderich R. Purification and catalytic properties of Ech hydrogenase from Methanosarc ina barkeri. Eur J Biochem 1999; 265:325-335. PubMed http://dx.doi.org/10.1046/j.14321327.1999.00738.x

40. Wu M, Ren Q, Durkin AS, Daugherty SC, Brinkac LM, Dodson RJ, Madupu R, Sullivan SA, Kolonay $J F$, Haft DH, et al. Life in hot carbon monoxide: the complete genome sequence of Carboxydotherm us hydrogenoformans Z-2901. PLoS Genet 2005; 1:e65. PubMed http://dx.doi.org/10.1371/journal.pgen.0010065

41. Fox JD, He Y, Shelver D, Roberts GP, Ludden PW. Characterization of the region encoding the CO-induced hydrogenase of Rhodospirillum rubrum. J Bacteriol 1996; 178:6200-62 08. PubMed

42. Sokolova TG, Henstra AM, Sipma J, Parshina SN, Stams AJ, Lebedinsky AV. Diversity and ecophysiological features of thermophilic carboxydotrophic anaerobes. FEMS Microbiol Ecol 2009; 68:131-141. PubMed http://dx.doi.org/10.1111/j.1574$\underline{6941.2009 .00663 . x}$ 
43. Spring $S$, Visser $M$, Lu M, Copeland A, Lapidus A, Lucas S, Cheng JF, Han C, Tapia R, Goodwin LA, et al. Complete genome sequence of the sulfatereducing firmicute Desulfotomaculum rum in is type strain (DL(T)). Stand Genomic Sci 2012; 7:294-309. PubMed http://dx.doi.org/10.4056/sigs.3226659

44. Spring S, Lapidus A, Schroder M, Gleim D, Sims D, Meincke L, Glavina Del Rio T, Tice $H$, Copeland A, Cheng JF, et al. Complete genome sequence of Desulfotomaculum acetoxidans type strain (5575). Stand Genomic Sci 2009; 1:242253. PubMed http://dx.doi.org/10.4056/sigs.39508

45. Meyer B, Kuever J. Phylogeny of the alpha and beta subunits of the dissimilatory adenosine-5'phosphosulfate (APS) reductase from sulfatereducing prokaryotes--orig in and evolution of the dissimilatory sulfate-reduction pathway. Microbiology 2007; 153:2026-2044. PubMed http://dx.doi.org/10.1099/mic.0.2006/003152-0

46. Junier $P$, Junier $T$, Podell S, Sims DR, Detter JC, Lykidis A, Han CS, Wigginton NS, Gaasterland T, Bernier-Latmani R. The genome of the Grampositive metal- and sulfate-reducing bacterium Desulfotomaculum reducens strain MI-1. Environ Microbiol 2010; 12:2738-2 754. $\underline{\text { PubMed }}$

47. Kroger A, Biel S, Simon J, Gross R, Unden G, Lancaster CR. Fumarate respiration of Wolinella succinogenes: enzymology, energetics and coupling mechanism. Biochim Biophys Acta 2002; 1553:23-38. PubMed http://dx.doi.org/10.1016/S0005-2728(01)002 341

48. Venn diagram plotter available from the Pacific Northwest National Laboratory Software Distribution Center: http://omics.pnl.gov.
49. Staals RHJ, Brouns SJJ. Distribution and Mechanism of the Type I CRISPR-Cas Systems. In: Barrang ou R, van der Oost J, editors. CRISPR-Cas Systems: Springer; 2012. p 145-96.

50. Makarova KS, Haft DH, Barrang ou R, Brouns SJ, Charpentier E, Horvath P, Moineau S, Mojica FJ, Wolf YI, Yakunin AF, et al. Evolution and classification of the CRISPR-Cas systems. Nat Rev Microbiol 2011; 9:467-477. PubMed http://dx.doi.org/10.1038/nrmicro2577

51. Mobley HL, Hausing er RP. Microbial ureases: significance, regulation, and molecular characterization. Microbiol Rev 1989; 53:85-108. PubMed

52. Auch AF, von Jan M, Klenk HP, Goker M. Digital DNA-DNA hybridization for microbial species delineation by means of genome-to-genome sequence comparison. Stand Genom ic Sci 2010; 2:117-134. PubMed http://dx.doi.org/10.4056/sigs.531120

53. Wayne LG, Brenner DJ, Colwell RR, Grimont PAD, Kandler O, Krichevsky MI, Moore LH, Moore WEC, Murray RGE, Stackebrandt E, et al. Report of the Ad-Hoc-Committee on Reconciliation of Approaches to Bacterial Systematics. Int J Syst Bacteriol 1987; 37:463-464.

http://dx.doi.org/10.1099/00207713-37-4-463

54. Richter M, Rossello-Mora R. Shifting the genomic gold standard for the prokaryotic species definition. Proc Natl Acad Sci USA 2009; 106:1912619131. PubMed http://dx.doi.org/10.1073/pnas.0906412106

55. In: Lapage SP, Sneath PHA, Lessel EF, Skerman VBD, Seelig er HPR, Clark WA, editors. International Code of Nomenclature of Bacteria: Bacteriological Code, 1990 Revision. Washington (DC) 1992 . 